\title{
The wrong kind of freedom? A Review of David Graeber's The Utopia of Rules: On Technology, Stupidity and the Secret Joys of Bureaucracy (Brooklyn/London: Melville House, 2015, 261 pages)
}

\author{
Anastasia Piliavsky ${ }^{1}$
}

Published online: 12 January 2017

C The Author(s) 2017. This article is published with open access at Springerlink.com

Everybody hates bureaucracy-even bureaucrats hate bureaucracy (who likes stamping forms all day long?) — but David Graeber hates it more than most. He hates it with an anarchist's hate. The Utopia of Rules is a clever, freewheeling, readable, and frequently entertaining collection of essays (some previously published and some new) about bureaucracy as a violent force.

Bureaucracy, Graeber tells us, has swallowed the modern world whole. If 40 years ago, countless pamphlets, monographs, and satirical novels denounced the horrors and absurdities of bureaucratic life, today, although the world is more bureaucratized than ever, hardly anyone any longer complains about, or even cares to notice, the fact. "It's as if, as a planetary civilization, we have decided to clap our hands over our ears and start humming whenever the topic comes up" (p. 5). How did this happen? Graeber's argument runs roughly like this. Modern Euro-American bureaucracy is a holdover of the ancien régime: a newly clothed, but in its essence aristocratic, hierarchy of command. Its primary role has always been the regulation, and indeed the creation, of markets by governments (an argument Graeber set out in his earlier book Debt: the first 5000 years). In the late nineteenth century, private businesses started to adopt bureaucratic techniques, with the result that governments and businesses, especially in Germany and the United States, became increasingly difficult to distinguish in their modus operandi and culture. This is how corporations were born. After World War II, the USA set up global bureaucracies - the United Nations and the Bretton Woods organizations - thus projecting bureaucracy onto a planetary scale. The American bureaucrat, and faith in the bureaucratic compulsion, has since conquered the world and the minds of its denizens.

Anastasia Piliavsky

an379@cam.ac.uk

1 University of Cambridge, Cambridge, UK 
For ordinary people around the globe, bureaucracy is not just a source of infinite tedium, it is also the cause of existential violence. It violates our capacity to imagine, create, play, or even think clearly; and in so doing it infringes upon the very essence of what it means to be human, for imagination is what raises us above other mammals, writes Graeber, citing Edmund Leach. "Bureaucratic procedures... have an uncanny ability to make even the smartest people act like idiots" (p. 95). We all know the experience of ticking boxes, which depletes the will of even the most imaginative and playful. But Graeber sees in box-ticking more than a momentary numbing of the mind: bureaucracy "radically strips down, simplifies, and ultimately prevents communication ... it is really a form of anti-action" which interns the soul. Even more treacherously, the bureaucratic process deludes us into believing that its spurious rationality and impersonal quantitative techniques are sources - indeed the only viable sources - of equality, justice, and fairness in the world. This could not, however, be further from the truth. Bureaucracies are made of hierarchy and alienation, and they serve the private interests of political and economic elites. They are the "democratization of despotism" (p. 164).

Graeber is not simply whinging. His book is a manifesto with a clear political aim. What unsettles him at least as much as the iron clutch of bureaucracy is the fact that the political Left had lost its grip. As the rebellious 1960s receded into a quaint memory,

the mainstream Left has increasingly reduced itself to fighting a kind of pathetic rearguard action, trying to salvage remnants of the old welfare state... What is presented as the "moderate" Left solution to any social problems - and radical Left solutions are, almost everywhere now, ruled out tout court - has invariably come to be some nightmare fusion of the worst elements of bureaucracy and the worst elements of capitalism. It's as if someone had consciously tried to create the least appealing possible political position.... The result is a political catastrophe... Every time there is a social crisis, it is the Right, rather than the Left, which becomes the venue for the expression of popular anger (p. 6).

Many of the book's readers will no doubt share Graeber's concern and be very interested in his diagnosis. What they may find less convincing is the therapy he prescribes.

In Graeber's view, what the Left needs to consolidate its position is a critique of bureaucracy because "the Left, in its essence," he bracingly adds, "is a critique of bureaucracy." Its "current inability to formulate a critique of bureaucracy... is synonymous with the decline of the Left itself. Without such a critique, radical thought loses its vital center - it collapses into a fragmented scatter of protests and demands" (p. 83). "The Right, at least, has a critique of bureaucracy. It's not a very good one. But at least it exists" (p. 6). To anyone who grew up in the Soviet Union (as I did), this will sound like an implausible claim. Surely, the Left holds the welfare state-and the bureaucracy it requires - very dear. You do not need to look to the Soviet Union to see this point. John Maynard Keynes was (at one time in his life) a top bureaucrat, and dirigisme is a decidedly Leftist system. In fact, most Left-leaning governmental practice has historically lain somewhere between Swedish welfarism and the Khmer Rouge.

But Graeber stands for a different Left. A career anarchist, he wants liberation above all; more than welfare or public healthcare, and even more than social and economic justice, of which he's been a vociferous advocate. Graeber yearns for total liberation: liberation from government rules and regulations, from boredom and capitalism, inequality, law, corporations, tradition, and the police, and from 
bureaucracy's "soulless conformity." A young anarchist group, whose manifesto he approvingly quotes, gives voice to this yearning:

We must make our freedom by cutting holes in the fabric of this reality, by forging new realities which will, in turn, fashion us. Putting yourself in new situations constantly is the only way to ensure that you make your decisions unencumbered by the inertia of habit, custom, law, or prejudice - and it is up to you to create these situations.

Freedom only exists in the moment of revolution. And those moments are not as rare as you think. Change, revolutionary change, is going on constantly and everywhere - and everyone plays a part in it, consciously or not (pp. 96-97).

During the first two chapters the reader will find herself wavering between feeling that scales have been removed from her eyes and that conspiratorial wool has been pulled over them. But by the time we are asked to cut holes in the fabric of reality, the book begins to read like a millenarian screed.

But let's stick with Graeber's train of thought. What he seeks liberation from is quite clearanything that may stifle human playfulness, imagination, and will. Less apparent is what it is for. What kind of a world lies beyond the threadbare veil of false reality spun for us by American bureaucrats? And how do we get to the other side? Graeber writes, as he does in Debt, that his ultimate aim is "a world without states and capitalism" (p. 97), a world where the iron cage of bureaucracies, and indeed any abstracted regulatory regimes, would be obsolete. This sounds rather enticing. One would never have to fill out another form, never again stand in a queue for a visa. But how do we get there? "On this point," writes Graeber, "no one is completely sure" (ibid). "Endless improvization?" "Insurrectionary moments?” A "complex and multifaceted revolutionary process?"

Meanwhile, most of us need to eat, dress, live somewhere and, therefore, work. Some of us may need to take trains to work. Now, if you needed to take a train, would you or would you not prefer it to run on time? It may well be that Graeber does not like or need to take trains. Since he tells us that he does not drive a car, it may be that he is waiting for flying cars to come onto the market. (In chapter 2, he is genuinely aggrieved that, despite what he was told in the 1960s, there are still none around.) But it is difficult to imagine how a set of generalized services that require coordination - a railway system, a postal service, a network of hospitalscan work without abstracted procedures and rules. Can they operate on the "principles of direct democracy according to an elaborate... form of consensus process," which Graeber practiced as a member of the New York Direct Action Network (DAN) (p. 84)? DAN may well be "the best organized force" ever encountered by the NYPD (p. 85), but an amusing incident gives a sense of the organizational perils of direct democracy.

DAN did not have much of a budget, but one day, someone gave them a car, an event that precipitated a serious crisis of coordination and responsibility. In the US cars can be legally owned only by individuals or corporations, who are responsible for insuring, registering them, and paying fines. As DAN was neither an individual nor a corporation, one of its members volunteered to act as the car's legal owner. Very soon, this brave soul became responsible for insurance fees, multiple fines and for retrieving the car when somebody else in the group had it impounded, and life became rather a nightmare. Failing to agree on how to deal with these problems, DAN decided to throw a party at which guests could smash the car with a sledgehammer, for a fee. Graeber writes that American law, with its narrow definition of ownership and ascription of responsibility, was at fault. But to me it seems that the group's 
"elaborate consensus process" made it impossible to agree on who should do what, for whom, how, and when. Car smashing is a fine anarchist spectacle. Cathartic though this may be, it leaves behind only pieces that someone else needs to clean up. This liberation theology no doubt carries some psychological appeal - at least for those "of us [who] would like to smash a bank or [a] shopping mall at least once in our lives" (p. 213) - but it is difficult to see how it can add up to a coherent political outlook, let alone a political strategy.

Psychology has much to answer for here. Again and again, Graeber hangs his polemic on supposedly universal psychological states, like boredom or anxiety, which all humans supposedly abhor. Why is bureaucracy bad for us? It is because it makes us bored. Why does it nonetheless offer "secret joys?" It is because by making rules explicit, it removes the anxiety of living with ambiguous, unspoken rules. What good would removing bureaucracy do? It would liberate our minds for the fun and the play that we yearn for. For a serious social anthropologist like Graeber, this is an odd approach to adopt. Surely, not all humansincluding Americans and Brits - shape their political purposes through the categories of "fun," "angst," or "boredom." Many rituals studied by anthropologists around the world involve long hours of waiting and isolation, repetitive gestures, and incantations lasting hours, days, or even weeks. Yet no one - neither the anthropologists nor their informants - gets bored. Rituals are worth the wait because they do important work in society. They turn children into adults, and corpses into ancestors; they forge and sever relations, create and dissolve communities, affirm and shift loyalties, and they may even spark revolts.

Bureaucratic processes do the same kind of work. To be alive in a socially meaningful sense, it is not enough to emerge from your mother's womb; to be dead, it is not enough to die physically. To stand for elections or vote, it is not enough to know about a country's politics, nor is it enough to live somewhere to be a resident of that place. Who we are (alive, married, doctors, or students) and what we have (cars, children) depends on these facts being bureaucratically inscribed. The Indian Association of the Dead, whose 20,000 undead citizens have been falsely registered as deceased, fight to be recognized as living. Meanwhile, a dead candidate, whose death was not registered, recently won an election. Insofar as bureaucratic procedures perform transformative work through formalized and abstracted gestures and rules, it makes good sense for anthropologists to think of them as socially constitutive rituals.

Graeber recognizes that paperwork "actually effects change" (p. 50), but he does not want to take its social productivity seriously, the way he did with debt in his earlier book. While "traditional rituals"-Bemba female initiation or Balinese cockfights - are "infinitely rich" and "open-ended," he insists that paperwork is "designed to be maximally simple and self-contained." It "doesn't really open on anything outside itself"; it is a "vacuum," even an "abyss," and so "there isn't very much to interpret" (pp. 52-53). One may well feel vacuous or abysmal in the face of an interminable visa application or an Ethics Approval Form. But the sizeable anthropological literature on bureaucracy, and Graeber's own account of his bureaucratic adventures, show that there is nothing simplistic or hollow, nothing that would encourage "thin description" or generate writing too dull to read. If it was good enough for Gogol and Kafka, surely it is good enough for us. Only someone who has accepted Weber's ideal type as a fact of life would think that bureaucracy is inherently dull.

If, as Graeber (no doubt rightly) suggests, in the experience of many ordinary people, bureaucracy is a game - with rules and regulations, prizes, disqualifications, and arbitersthere is a world of difference between bureaucratic rules and how people play by them. It may be that the American clerks Graeber dealt with saw fastidious adherence to rules as their chief 
virtue, but much bureaucratic practice in the world is much more creative: self-aware, tactical, and even strategic. Few bureaucrats I have known in my life on four continents (including Europe and North America) think of themselves primarily as mere custodians of correct procedure.

I once tried to extend my research visa in a remote area of India. The clerk in the local visa office was visibly displeased: he was large, it was August, and the Desert Cooler was not coping well. He told me that I could secure my extension only in Delhi, not here. His no really meant no. Did the rulebook really require me to travel to Delhi or was he just making that up? Was this bureaucratic harassment because it was hot, because his boss was out today, or because he was fed up with helping rich, hapless white people? Whether or not one can fulfill one's bureaucratic needs depends largely on who happens to be at the desk and how much they like you. I have charmed my way through many bureaucratic scenarios, and all it usually took was the knowledge of local language and a couple of jokes, never a bribe.

Only rarely were my encounters with Indian bureaucrats impersonal. More often, they were filled with sympathies, purposes, and interests. I will never know whether my various extensions and permits were granted with the help of clerks who chose to overlook rules in my favor or whether I would have got them faster if they "just followed the rules." What I do know is that the Indian (and not only Indian) bureaucrats of all stripes are proud sovereigns of their domains - as masterful at circumventing the rules as at making them up-and that without their good will, your bureaucratic wishes will never come true. Their work is full of political, economic, and even moral imagination, and it pursues purposes that are anything but abstract. For them and their petitioners, it is a complicated, and often highly personal, game that relies on a calculus of written rules, but cannot be reduced to it.

Bureaucracies, from ancient Mesopotamia to Xi Jinping's China, carry emphatic dangers and sometimes appear in hideous form, but they have also made it possible to coordinate social life on a large scale since the invention of writing. Graeber can hope to wish bureaucracy away, but by swapping regulation for autonomy, free choice, and the primacy of individual judgment, he risks collusion with libertarians and the Right.

Open Access This article is distributed under the terms of the Creative Commons Attribution 4.0 International License (http://creativecommons.org/licenses/by/4.0/), which permits unrestricted use, distribution, and reproduction in any medium, provided you give appropriate credit to the original author(s) and the source, provide a link to the Creative Commons license, and indicate if changes were made. 